\title{
Anatomical and Histological Structure of Reproductive Organs in Male Flying Squirrel Hylopetes Lepidus (Horsfield, 1822)
}

\author{
Shanghnesy Jovita Nirvana ${ }^{1 *}$, Muhammad Ja'far Luthfi ${ }^{2}$, Erna Ekasari ${ }^{3}$, Lailatul Maghfiroh ${ }^{3}$ \\ ${ }^{1}$ Postgraduate Program, Universitas Sebelas Maret \\ Jl. Ir. Sutami 36 A, Surakarta, 57126, Tel. +62271-646994, Fax. +62271-646655, Indonesia \\ ${ }^{2}$ Biology Education Department, ${ }^{3}$ Biology Department, Faculty of Science and Technology, UIN Sunan Kalijaga \\ Jl. Marsda Adisucipto No 1 Yogyakarta 55281, Indonesia. Tel. +62-274-540971, Fax. +62-274-519739 \\ Email: shanghnesyjovita@gmail.com
}

\begin{abstract}
Flying squirrel (Hylopetes lepidus) is an Eutherial mamal (placental mammal), belong to the order Rodentia and belong to the family Sciuridae. Hylopetes lepidus had gray cheek as its unique characteristics. The reproductive organs are the key to success in maintaining the new descendants. Male reproductive organs will produce the male sex cells or spermatozoa. The purpose of the research is to examine the anatomical structure, morphometry, histomorphometry, and histological structure of male reproductive organs (penis, testicle, vas deferens, bulbouretralis gland, prostate and seminal vesicles) of Hylopetes lepidus. The method used in examining histological characteristics is Hematoxyin-Eosin staining method. The histological structure of reproductive organs were observed using optilab microscope. The results of the study showed that the adult male flying squirrel weighed $104.28 \pm 0.64$ gram. Anatomically, it has oval white reddist testicle. The testicle is located side out of the body cavity in the scrotum. Morphometric observation testicular showed that the right testes has volume $0.35 \pm 0.07 \mathrm{ml}$, and the left has volume $0.35 \pm 0.07 \mathrm{ml}$, weight of the right testicular $0.19 \pm 0.01$ gram, weight of the left testicular $0.18 \pm 0.01$ gram, diameter of the right testicular $6.35 \pm 0.21 \mathrm{~mm}$, diameter of the left testicular 6.35 $\pm 0.21 \mathrm{~mm}$, short diameter of the right testicular $3.45 \pm 0.21 \mathrm{~mm}$, and short diameter of the left testicular $3.45 \pm 0.21 \mathrm{~mm}$. The diameter of tubulus seminiferus $261,4 \pm 0.14 \mu \mathrm{m}$. The conclusion of this study compared to rodentia other testicular Hylopetes lepidus has a unique testicular bound by the connective tissue in the scrotum so that testicular included in class permanent descending testicular. The rhombus of the prostate gland are blunt, while histologically the sertoli cells in the seminiferus tubule shaped elongated, while in morphometry penis Hylopetes lepidus relatively longer than Mus musculus.
\end{abstract}

Keywords: Anatomical, Histomorphometry, Male Hylopetes lepidus, Morphometry, Testicle

\section{INTRODUCTION}

Indonesia has a diversity of natural resources in it, including various kinds of animals. The animals are spread throughout the islands in Indonesia. Indonesia is one of the seven megabiodiversity countries known as the center of world biodiversity. One of Indonesia's species diversity is mammal diversity with a total of 436 species and $51 \%$ of them are endemic species (Dede et al., 2008). Flying squirrel Hylopetes lepidus itself is an endemic animal in Java.

Animals in Indonesia are now facing a serious problems with an increasingly rapid rate of extinction due to the evolution of humanity on earth and human beings who unwise in manage the nature. Animal populations that were once a lot are now decreasing and are starting to be threatened and can lead to extinction. The number of animals that need to be protected as listed in PP No. 7 of 1999 proves that the survival of endangered species is now increasingly threatened by its population.

The reproduction of male and female flying squirrels (Hylopetes lepidus) plays an important role in maintaining their species and diversity so they do not become extinct. But the scope of this study only limited on the study of reproductive organs in male flying squirrels. Male reproductive organ produces male sex cells or spermatozoa. Research on the anatomy and histology of reproductive organs is important to determine the sperm maturity process in the flying squirrel reproductive organs. Considering each species has a different reproductive structure such as the anatomical structure of the reproductive tract which will be strongly related to the physiological functions of the organs in the species (Phadmacanty et al., 2013).

\section{MATERIALS AND METHODS}

The study was conducted for 2 months from June to July 2016 in Zoology Laboratory of UIN Sunan Kalijaga and BPPH Veteriner, Wates. Anatomical observations and morphometry of male flying squirrel reproductive organs were carried out by anesthesia using subsequent chloroform. The organs were surgically removed. The morphometric and histomorphometric measurements include the penis, testes, epididymis, vas deferens, bulbourethal gland, prostate and seminal vesicles. Morphometry of reproductive organs measured using an analytical balance sheet, length and diameter were measured using a caliper and volume using a $5 \mathrm{ml}$ measuring cup. Whereas histomorphometry uses histology preparations by performing measurements using optilab microscope. Making histology slides with Hematoxylin-Eosin staining method. 


\section{RESULTS AND DISCUSSION}

\section{Anatomical Structure}

The results shows that the testicles in the flying squirrel species had an oval-shaped reddish white color, amounting to a pair located on the left and right and with longitudinal vein strokes (Image 1). Testis of Hylopetes lepidus is located in the pelvic area inside the scrotum. Seen in the ductal epididymal duct, this duct starts from the top of the testis which is the head of the epididymis and ends in the tail of the epididymis. The testes themselves are outside the abdominal cavity which is inside the scrotum.

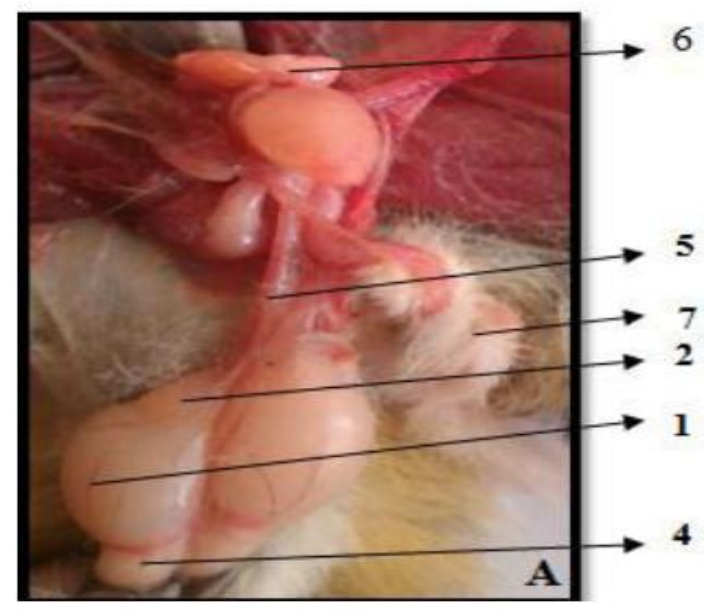

Figure 1. Anatomy of the male reproductive system of Hylopetes lepidus (1) Testis, (2) Epididymal head, (3) Epididymal corpus, (4) Cauda epididymis, (5) Vas deferens, (6) Seminal vesicles, (7) Penis.

The epididymis looks like a long, winding pipe with a number in the right and left testes. The epididymis itself is reddish white as well as the testicles. The location of the epididymis itself is attached to one side of the testis from anterior to posterior. Epididymis is divided into three parts: caput, corpus and cauda epididymis. Caput is anterior to the testis. The corpus is in the middle and extends slender along the side of the testis. Cauda is at the end or tail. The epididymis acts as a storage place and spermatozoa maturation (Yatim, 1992). Vas deferens (Figure 2) appears reddish white, the shape of the vas deferens itself is a long channel shaped like a pair of long pipes located on the left and right located straight upward which is a continuation of the epididymis.

Seminal vesicle glands have a reddish white color. The morphological forms of the seminal vesicle gland differ in each species (Hafez, 2000). Image 2 shows that the testes are firmly attached to the scrotum so that the testicles cannot be pulled out of the scrotum cavity. Hylopetes lepidus testis categorized in permanent descending testis where the testicles remain in the pelvic area in the scrotum. The tip of the cauda epididymis is bound by connective tissue (Image 1) so that the testis cannot return to the abdominal cavity. Whereas generally in Rodentia, some insectivorous animals, bats, beavers, and pigs are classified as temporary decendent testicles where the testes will descend from the abdominal cavity to the pelvic cavity in the scrotum through the inguinal canal if the mating season, when the genitals it has passed the testis will return to the abdominal cavity. This animal group the inguinal canal has not been covered by connective tissue (Chaeri, 2005).

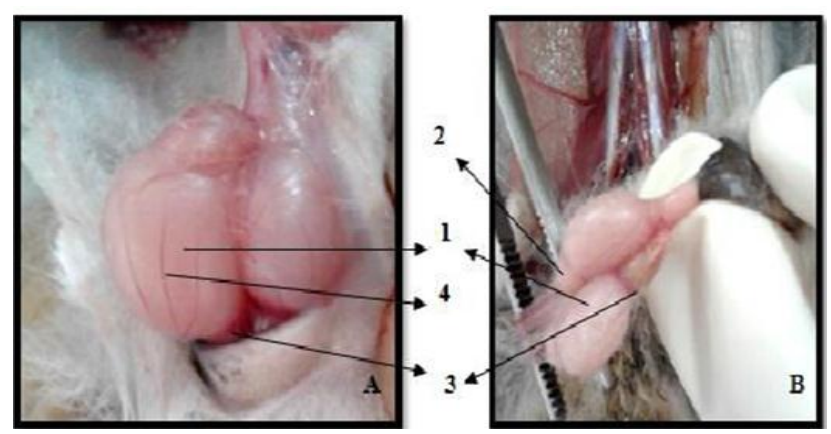

Figure 2. (A): Anatomical structure of Hylopetes lepidus testes (A) the testes attached to scrotum 1) Testis, (2) Caput of epididymis, (3) Cauda epididymis, (4) Stroke of blood vessels, (B): Tip of cauda epididymis atrracted to connective tissue (1) Testis, (2) Caput of epididymis, (3) Cauda epididymis, (4) Stroke of blood vessels.

Figure 3 The prostate gland is shaped like a rhombus with a blunt end, a number of pairs located on the right and left. The prostate gland is located in the dorsal surface of the urinary vesica and base of the urethra. Like the seminal vesicles, the location of the prostate gland also varies in each species. The penis looks like a tube and has a relatively long size, and is outside the body cavity, like most other mammals. The color of the penis itself is reddish white.

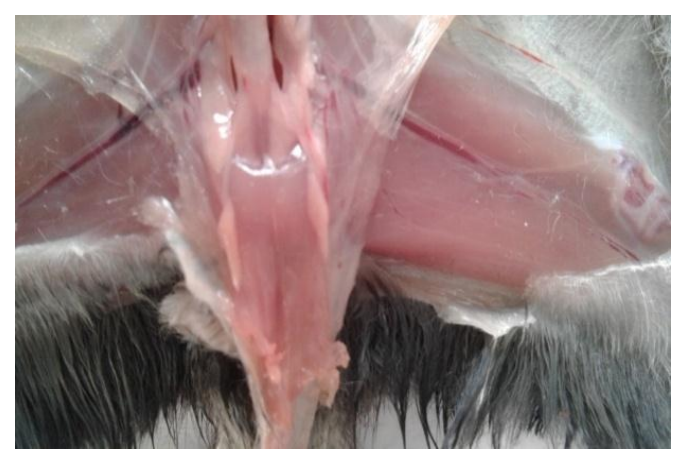

Figure 3. A pair of prostate gland in male Hylopetes lepidus.

\section{Morphometry and Histomorphometry Measurement of Reproductive Organs in Hylopetes lepidus (Horsfield, 1822)}

Reproductive organs in mammals have a variety of different shapes and sizes in each species. Mammals generally have male reproductive organs that are in pairs. The size of the reproductive organs in the flying squirrel (Hylopetes lepidus) can be seen in (Table 1). The testicular organs have a greater right testicular volume than the left testis, as well as the weight of the right testicle is greater than the weight of the left 
testicle. Hylopetes lepidus has the same right long diameter and left long diameter, so does the value of the right short diameter and short left diameter. Length of the right epididymis and the left relatively the same as right and left epididymal volume, when compared with Mus musculus epididymis which is $11.77 \pm 1.07$ $\mathrm{mm}$ flying squirrels have a longer epididymis. Hylopetes lepidus has a left vas deferens longer than the length of the right vas deferens, when compared with the Mus musculus vas deferens which is $18.80 \pm$ $1.21 \mathrm{~mm}$ vas deferens Hylopetes lepidus is longer, and has a relatively long penis size compared to other mammals namely Musculus penis $22.75 \pm 1.81 \mathrm{~mm}$ (Ekayanti, 2013).

Table 1. Morphometry data of reproductive organ in Hylopetes lepidus.

\begin{tabular}{|c|c|c|c|}
\hline No. & Organs & Parameter & $\begin{array}{l}\text { Measurement } \\
\text { Result }(\mu \mathrm{m})\end{array}$ \\
\hline 1. & $\begin{array}{l}\text { Seminiferous } \\
\text { tubule }\end{array}$ & $\begin{array}{l}\text { Diameter of } \\
\text { seminiferous tubule }\end{array}$ & $261,4 \pm 0.14$ \\
\hline \multirow[t]{3}{*}{2.} & $\begin{array}{l}\text { Epididymis } \\
\text { caput }\end{array}$ & $\begin{array}{l}\text { Diameter of Outer } \\
\text { Epididymis }\end{array}$ & $198,4 \pm 0.70$ \\
\hline & & $\begin{array}{l}\text { Diameter of Inner } \\
\text { Lumen }\end{array}$ & $181,3 \pm 0.77$ \\
\hline & & $\begin{array}{l}\text { Length of } \\
\text { Epithelium }\end{array}$ & $13.0 \pm 2.75$ \\
\hline \multirow[t]{3}{*}{3.} & $\begin{array}{l}\text { Corpus } \\
\text { epididymis }\end{array}$ & $\begin{array}{l}\text { Diameter of Outer } \\
\text { Epididymis }\end{array}$ & $214,6 \pm 0.70$ \\
\hline & & $\begin{array}{l}\text { Diameter of Inner } \\
\text { Lumen }\end{array}$ & $197,6 \pm 0.77$ \\
\hline & & $\begin{array}{l}\text { Length of } \\
\text { Epithelium }\end{array}$ & $11.9 \pm 0.21$ \\
\hline \multirow[t]{3}{*}{4.} & $\begin{array}{l}\text { Cauda } \\
\text { epididymis }\end{array}$ & $\begin{array}{l}\text { Diameter of Outher } \\
\text { Epididymis }\end{array}$ & $257,1 \pm 0.70$ \\
\hline & & $\begin{array}{l}\text { Diameter of Inner } \\
\text { Lumen }\end{array}$ & $228,5 \pm 1.97$ \\
\hline & & $\begin{array}{l}\text { Length of } \\
\text { Epithelium }\end{array}$ & $10.15 \pm 0.49$ \\
\hline
\end{tabular}

Table 2. Histomorphometry data of reproductive organ in male Hylopetes Lepidus.

\begin{tabular}{|c|c|c|c|c|}
\hline No & Organs & Parameter & Right & Left \\
\hline \multirow[t]{4}{*}{1.} & Testes & $\begin{array}{l}\text { Volume } \\
(\mathrm{ml})\end{array}$ & $0.45 \pm 0.07$ & $\begin{array}{l}0.35 \pm 0.0 \\
7\end{array}$ \\
\hline & & $\begin{array}{l}\text { Weight } \\
\text { (gram) }\end{array}$ & $0.19 \pm 0.01$ & $\begin{array}{l}0.18 \pm 0.0 \\
1\end{array}$ \\
\hline & & $\begin{array}{l}\text { Long } \\
\text { diameter } \\
(\mathrm{mm})\end{array}$ & $6.35 \pm 0.21$ & $\begin{array}{l}6.35 \pm 0.2 \\
1\end{array}$ \\
\hline & & $\begin{array}{l}\text { Short } \\
\text { diameter } \\
(\mathrm{mm})\end{array}$ & $3.45 \pm 0.21$ & $\begin{array}{l}3.45 \pm 0.2 \\
1\end{array}$ \\
\hline \multirow[t]{2}{*}{2.} & Epididimis & $\begin{array}{l}\text { Length } \\
(\mathrm{mm})\end{array}$ & $17.5 \pm 3.53$ & $\begin{array}{l}17.5 \pm 3.5 \\
3\end{array}$ \\
\hline & & $\begin{array}{l}\text { Volume } \\
(\mathrm{ml})\end{array}$ & $0.25 \pm 0.07$ & $\begin{array}{l}0.25 \pm 0.0 \\
7\end{array}$ \\
\hline 3. & $\begin{array}{l}\text { Vas } \\
\text { deferens }\end{array}$ & $\begin{array}{l}\text { Length } \\
(\mathrm{mm})\end{array}$ & $19.0 \pm 1.41$ & $\begin{array}{l}19.15 \pm 1 . \\
20\end{array}$ \\
\hline & $\begin{array}{l}\text { Seminal } \\
\text { vesicle }\end{array}$ & $\begin{array}{l}\text { Volume } \\
(\mathrm{ml})\end{array}$ & $0.15 \pm 0.07$ & \\
\hline 5. & Penis & $\begin{array}{l}\text { Length } \\
(\mathrm{mm})\end{array}$ & $65.0 \pm 7.07$ & \\
\hline
\end{tabular}

Histomorphometric measurements were carried out using measurement methods with the help of the optilab ruler microscope, the results of which can be seen in (Table 2). Lumen diameter, epithelium height and epididymal diameter have different sizes in 3 parts found in the epididymis, namely cauda, caput and corpus epididymis. The size of the diameter of the caput is smaller than that of the corpus and cauda epididymis, this is because the anatomical structure of the epididymal head is narrowed and elongated. There are differences in the size of the lumen diameter in the 3 parts of the epididymis, namely in the head, body and cauda epididymis. The cauda area has the most extensive lumen diameter compared to the head and corpus epididymis because cauda epididymis has the lowest epithelium height. While the corpus epididymis has a lumen that contains spermatozoa that are denser than the head and corpus epididymis. The cauda is the largest repository of spermatozoa in the epididymis. About $75 \%$ of the total amount of spermatozoa in the epididymis is found in the cauda epididymis region (Boediono, 2000).

The epithelium columnar height of the epididymal caput is higher with stereocilia which is longer than the corpus and cauda epididymis. However, lower levels of pseudo-columnar epithelium with stereosilia are shorter than in the corpus epididymis. The difference in the height of the epithelium observed in this study correlates closely with the function of each part of the epididymis as a channeling organ, maturation, and storage of spermatozoa. When passing through the head and corpus epididymis, the spermatozoa undergoes morphological and functional changes and undergoes maturation, so that when it reaches the cauda epididymis, the spermatozoa are fertile (Wahyuni et al., 2012). The epithelium height in the epididymal head is higher than in the corpus and cauda epididymis. However, the cauda is lower than the corpus epididymis. The caput and corpus epididymis play a role in the process of cell plasma secretion and absorption of fluids originating from the seminiferous tubules of the testes needed for the maturation of spermatozoa. After going through the process of maturation in the head and corpus, spermatozoa are stored in the cauda epididymis with the lowest diameter and the lowest epithelium. This process greatly affects the height of columnar cells in each part of the epididymis. The head and corpus epididymis require a larger process of plasma cell secretion and absorption to help the early stages of spermatozoa maturation, therefore the height of columnar cells has the highest size compared to the corpus and cauda epididymis. Table 2 shows a comparison between the diameter of the seminiferous tubules of the greater Hylopetes lepidus, which is $261.4 \pm 0.14 \mu \mathrm{m}$ compared with Mus musculus which is $206.68 \pm 6.04 \mu \mathrm{m}$ (Rumanta, 2001). However the epithelium height in caput, corpus and cauda epididymis Mus musculus is higher than caput, corpus and cauda epididymis Hylopetes lepidus (Abbas et al., 2015). According to Arsyad (2014) the amount of 
testosterone hormone affects the thickness and height of the epididymal epithelium. The hormone testosterone regulates the cell morphology of the epididymal epithelium. If testosterone decreases, the morphology of epididymal epithelial cells decreases the thickness and height of the epithelium. This shows that Mus musculus has more testosterone than Hylopetes lepidus.

\section{Microscopic Anatomy of Reproductive Organ in Male Hylopetes leidus (Horsfield, 1822)}

The most important reproductive organs for male animals are the testicles. The testis has two functions, namely as a place for spermatogenesis and androgen production. Spermatogenesis occurs in a structure called tubule simineferus which will later produce spermatozoa when the animal reaches puberty, the testes will also produce the hormone testosterone. Flying squirrel testicles (Hylopetes lepidus) are protected by thick connective tissue capsules, namely tunica albuginea which is composed of dense collagen fibrous tissue. Interstitial connective tissue surrounds or encloses the tubules of simineferus.

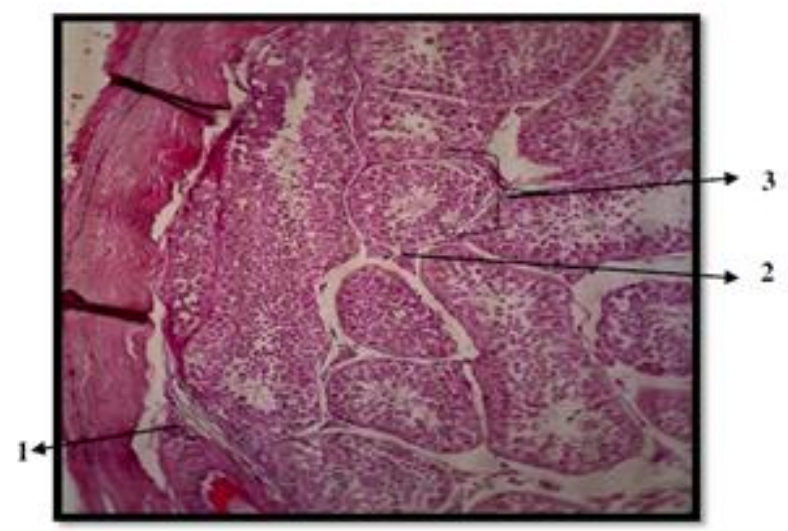

Figure 4. Cross section of Hylopetes Lepidus testis. Stained in HE Magnification 100x. (1) Interstitial connective tissue, (2) Leydig cell, (3) Semineferus tubule.

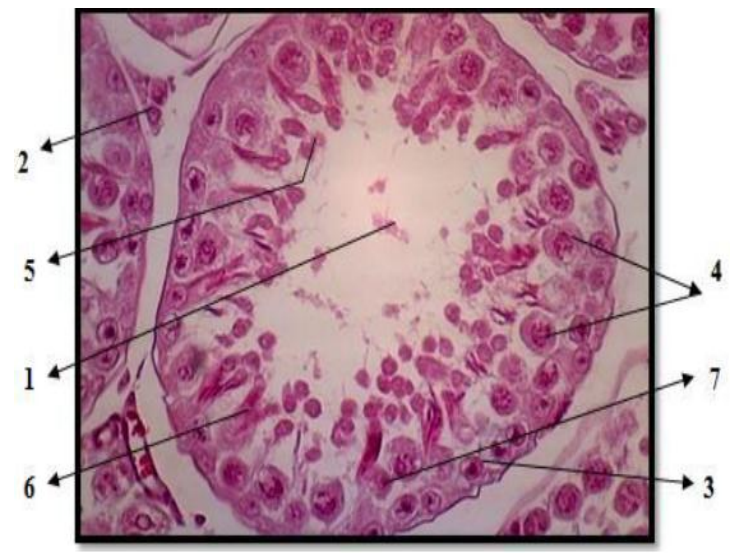

Figure 5. Cross section of seminiferus tubule in Hylopetes Lepidus. Stained in HE. Magnification 400 x. (1) Lumen with spermatozoa, (2) Interstitial (Leydig) cell, (3) Spermatogonia (4) Primer spermatocyte, (5) Spermatid, (6) Sertoli cell, (7) Secondary spermatocyte.
Spermatogenesis includes maturation of germinal epithelial cells by cell division and differentiation. This aims to form functional sperm. Seminiferus tubules consist of a large number of germinal epithelial cells or seed epithelial cells. Germinal epithelial cells consist of spermatogonia, spermatocytes and spermatids. Sertoli cells in Hylopetes lepidus are elongated in shape and function to nourish spermatozoa.

\section{Epididymis}

The epididymal duct in Hylopetes lepidus (Figure 6) is a long and winding duct. The ductal epididymal tubules are lined with stereosilia pseudo-pile columnar epithelium. Visible epididymal ductal tubules containing lumen containing mature spermatozoa.

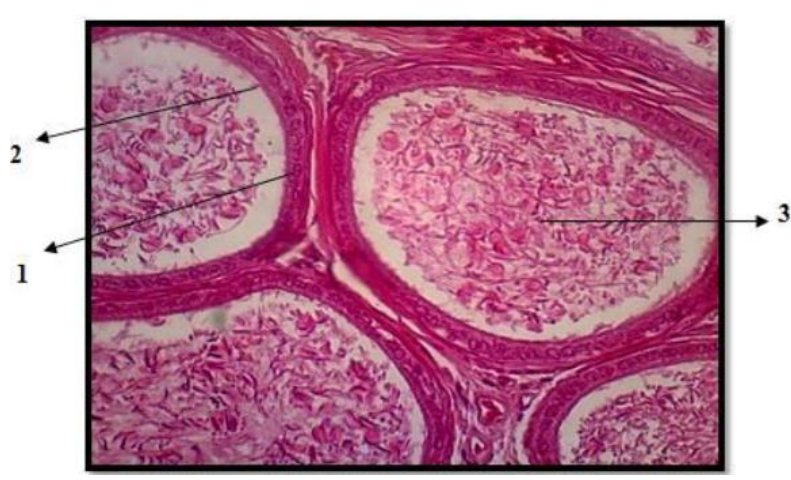

Figure 6. Cross section of epididymis corpus in Hylopetes Lepidus. Stained in HE. Magnification 400x. (1) Pseudostratisfied columnar epithelium (2) Stereocilia, and (3) Lumen that contains mature spermatozoa cell.

Three parts of epididymis can be distinguished, namely caput, corpus and cauda epididymis. The histological structure differences between the constituent components of caput, cauda and corpus epididymis include epididymal diameter, lumen diameter and epithelium height which have different columnar epithelium cell types in each section.

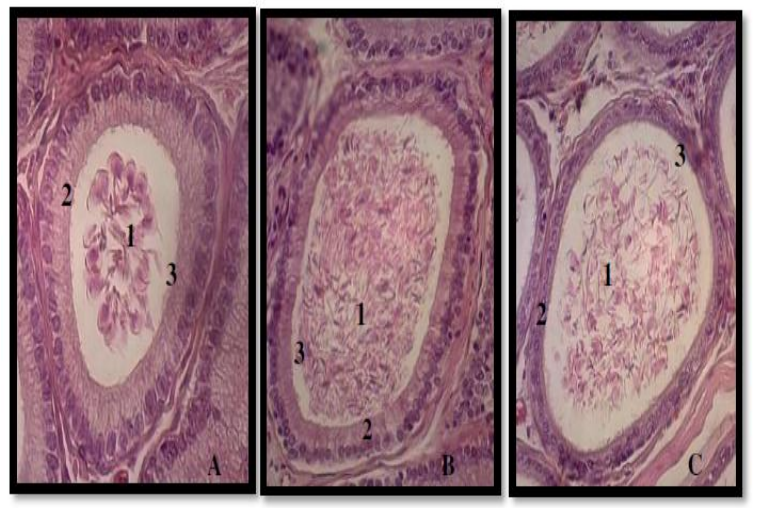

Figure 7. Cross section of epididymis in Hylopetes Lepidus. Stained in HE. Magnification 400x (A) Epididymis caput, (B) Corpus epididymis, (C) Cauda epididymis, (1) Lumen that contains spermatozoa, (2) Pseudostratified columnar epithelium, (3) Stereocilia. 
In addition to the histomorphometry discussed above, it was found that in the epididymal head the thicker and higher level of pseudo-columnar epithelium with stereosilia was higher and longer than the cauda epididymis. The histological structure differences observed in this study correlate closely with the function of each part of the epididymis as the channeling organ, maturation and storage of spermatozoa. When passing through the head and corpus epididymis, the spermatozoa undergoes a series of morphological changes and undergoes a process of maturation. So that when it reaches the cauda epididymis, spermatozoa are fertile (Wahyuni et al., 2012). The high presence of low epithelium, especially in the head and corpus epididymis, plays a role in the process of cell plasma secretion and absorption of fluid originating from the seminiferous tubules of the testes needed for the maturation of spermatozoa. After going through the process of maturation in the head and corpus, spermatozoa are stored in the cauda epididymis with the lowest diameter and the lowest epithelium. The caput and corpus epididymis requires a larger plasma cell secretion and absorption process for the early stages of spermatozoa maturation so that columnar epithelial cells have the highest size and have longer stereosilia than cauda epididymis. The largest lumen diameter is also found in the cauda epididymis compared to the corpus and capid epididymis. The lumen diameter is influenced by the height of the epithelium. The caput area has the highest epithelium height, therefore the lumen diameter in the epididymal head is elongated and narrowed. The epididymis of Hylopetes lepidus in all three areas of head, corpus, and cauda shows the lumen that has contained mature spermatozoa. This indicates that the flying squirrel has grown with a body weight of $104.28 \pm 0.64$ grams.

\section{Vas Deferens}

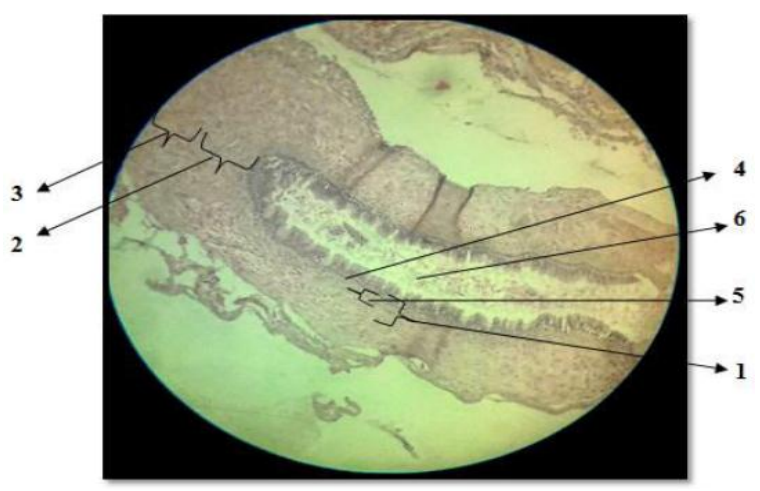

Figure 8. Longitudinal section of Vas deferens in Hylopetes Lepidus. Stained in HE. Magnification 400x. (1) Tunica mucosa, (2) Inner tunica muscularis, (3) Outer tunica muscularis, (4) Pseudostratified columnar epithelium, (5) Lamina propria, (6) Lumen that contains spermatozoa cells.
The vas deferens is also known as the ductus deferens. Vas deferens is a channel that acts as an introduction to sperm to the urethra. Vas deferens Hylopetes lepidus shows a tunica mucosa, which consists of a multilevel pile of columnar epithelium tissue, below the level pseudo columnar epithelium there is lamina propria. The tunica muscularis is longitudinal deep and the outer longitudinal tunica muscularis is below the tunica mucosa which consists of smooth muscle (Figure 8).

\section{Seminal Vesicle}

Structure of the microscopic component of the seminal vesicles of Hylopetes lepidus (Figure 9). The mucosal vesicles of the seminal vesicles of the Hylopetes lepidus appear to have an irregular lumen in the middle and are limited by a multilevel pseudo columnar epithelial.

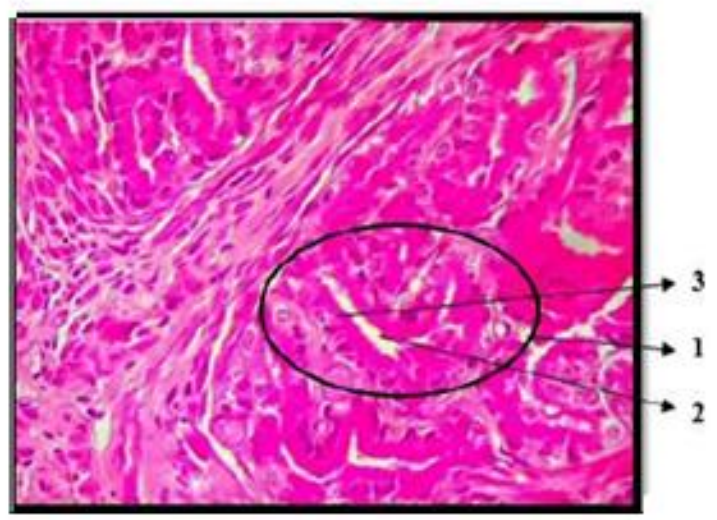

Figure 9. Cross section of seminal vesicle of Hylopetes Lepidus. Stained in HE. Magnification 400x (1) Mucose gland, (2) Lumen of seminal vesicle, (3) Pseudostratified columnar epithelium.

\section{Bulbourethral Gland}

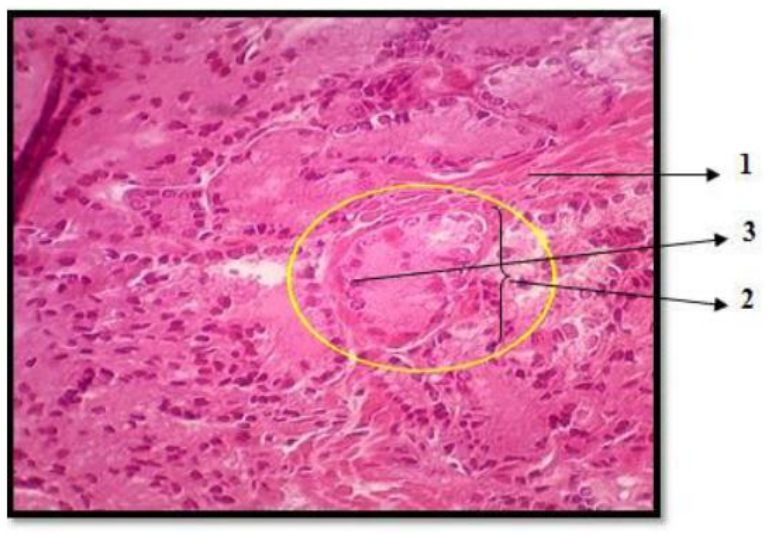

Figure 10. Cross section of bulbourethral gland in Hylopetes Lepidus Stained in HE. Magnification 400x (1) Smooth muscle tissue (2) Secretoric tubular unit, (3) Simple columnar epithelium.

The bulbourethral gland Hylopetes lepidus appears several tubular secretory units that are surrounded by a layer of columnar epithelium cells, and smooth muscle 
tissue. Secret produced by a thick, clear prostate that is released during erotic stimulation and functions as a lubricant for the urethra of the penis during ejaculation (Eroschenko \& Victor, 2014). This secret is also useful as a neutralizing and cleaning urethral duct from the rest of the dirt before the sperm is ejaculated (Hafez, 2000).

\section{Penis}

Figure 11 shows the part of the glands penis with the visible parts of the penis urethra stretching along the penis. A thin Lamina propria appears under the urethra of the penis, surrounded by several blood vessels, and the presence of several urethral glands.

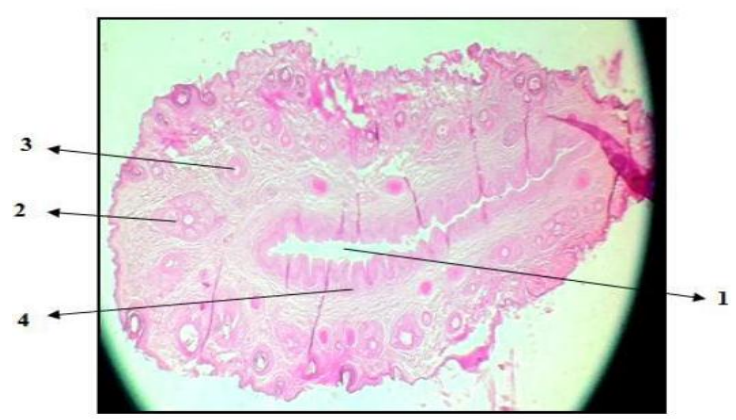

Figure 11. Cross section of glans penis of Hylopetes Lepidus. Stained in HE. Magnification 40x (1) Penis urethral, (2) Urethralis gland (littre), (3) Blood vessels, (4) Lamina propria.

The penis of Hylopetes lepidus in this study was observed in the gland of the penis and there was no visible tubulum, therefore there is no certainty whether there is a bakulum (os penis). Whereas in the notos Callosciurus species there is a bakulum (os penis) which is formed from true bone at the tip of the penis (Zaki, 2013).

\section{CONCLUSIONS}

The conclusion of this study compared to rodentia other testicular Hylopetes lepidus has a unique testicular bound by the connective tissue in the scrotum so that testicular included in class permanent descending testicular. The rhombus of the prostate gland are blunt, while histologically the sertoli cells in the seminiferus tubule shaped elongated, while in morphometry penis Hylopetes lepidus relatively longer than Mus musculus.

\section{ACKNOWLEDGMENTS}

The author would like to thank to the management of apprenticeship program of faculty of science and technology for guidance during the research, to the management of biology, medicine and natural product chemistry \& kaunia journal for assistance in paper writing.

\section{REFERENCES}

Abbas, T., Kwaraja, R. A., Asmat, U., Samreen, I., \& Kausar, R. 2015. Mitigating Effects of Jambul Against Lead Induced Toxicity in Epididymis and Vas deferens of mice. Journal Iran J Reprod, 13 (1), pp $721-728$.

Arsyad., Cholifah. C., \& Salni. 2014. Pengaruh Pemberian Ekstrak Pare (Momordica charatia, L) Terhadap Struktur Histologi Testis dan Epididimis Tikus Jantan (Rattus norvegicus) Spraque Dawley. MKS 46 (2).

Boediono, A., Noviana, C., Wresdiyati, T. 2000. Morphology And Histomorphometry Of Testis And Epididymis Of Kacang Goat (Capra sp) And Local Sheep (Ovis sp). Media Veteriner. 7 (2), $12-16$.

Chaeri, A. (2005). Struktur Hewan. Jakarta: Universitas terbuka.

Dede, A. R., Eko, P.R., \& Yanto, S. 2008. Study Of Mammals Diversity in Several Habitat Types in Pondok Ambung Research Station of Tanjung Puting National Park Central Kalimantan. Media Konservasi, 13 (3), 1 - 7.

Ekayanti, M. K. 2013. Seminar Nasional dan Forum Komunikasi Industri Peternakan. Dalam Pengaruh Pemberian Ekstrak Buah Merah (Pandanus conoideus lam) Terhadap Karakteristik Organ Reproduksi Jantan Dan Kualitas Sperma Mencit (Mus musculus). Bogor: Pusat Penelitian Bioteknologi Lembaga Ilmu Pengetahuan Indonesia. (pp. 246 - 256).

Eroschenko \& Victor, P. 2014. Atlas Histologi difiore. Jakarta: Buku Kedokteran EGC.

Hafez., E.S.E., 2000. Reproduction in Farm Animals. Hafez ( 7 th ed.). Lippincott William \& Willkins. A Wollter Kluwer Company.

Phadmacanty, R.P.N., Nugraha, P.T.R, \& Wirdateti. 2013. Reproductive Organ of Male Sulawesi Giant Rat (Paruromys dominator). Sains Veteriner, 31 (1), 0126 - 0421

Rumanta, M., Tien, W. S., \& Sri, S. 2001. Pengaruh Asam Metoksiasetat Terhadap Organ Reproduksi Mencit (Mus musculus) Swiss Webster Jantan. Jurnal PROC, 33 (2).

Wahyuni, S., Srihadi, A., Muhammad, A., \& Tuty, L. Y. 2012. Histology And Histomorphometry Of The Testis And Epididymis Of Muntjac (Muntiacus Muntjak Muntjak) During Hard Antler Period). Jurnal Veteriner, 13 (3), $211-$ 219.

Yatim, W. 1996. Histologi. Bandung: Tarsito.

Zaki, M. N. 2013. Studi Anatomi Dan Histologi Organ Urogenital Bajing Kelapa Jantan (Callosciurus notatus Boddaert, 1785). [Skripsi]. 